\title{
Hemagglutinin stalk-based monoclonal antibody elicits broadly reactivity against group 1 influenza A virus
}

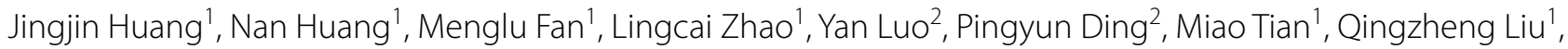
Yanna Guo ${ }^{1}$, Jinhua Zhao ${ }^{1}$, Yiqing Zheng ${ }^{1}$, Haitao Zhang ${ }^{2^{*}}$ and Jihui Ping ${ }^{1 *}$

\begin{abstract}
Background: Influenza virus remains a continuous and severe threat to public health worldwide, and its prevention and treatment have always been a major international issue. Because of its ability to evade immune surveillance through rapid antigenic drift and antigenic shift, broad-spectrum vaccines seem increasingly important.

Methods: $\mathrm{A}$ mAb named $3 \mathrm{C} 12$ from an immortalized hybrid cell was generated via immunizing mice with $\mathrm{HA} 2$ protein from A/chicken/Anhui/BRI99/2016 (AH/BRI99/16, H9N2) generated by prokaryotic expression. Then, its broadspectrum activity was analyzed by WB and IFA. Next, the minimal linear epitope was identified via analyzing the reaction of a series of HA truncations with $3 \mathrm{C} 12$. Finally, the protective effects of $3 \mathrm{C} 12$ were evaluated in vitro and in vivo infection experiments.

Results: The mAb could react with the viruses of subtypes $\mathrm{H1}, \mathrm{H2} 2 \mathrm{H} 5, \mathrm{H} 8, \mathrm{H} 9, \mathrm{H} 12, \mathrm{H} 13, \mathrm{H} 16$, and $\mathrm{HA}$ protein of $\mathrm{H} 18$ in group 1, but failed to react with viruses in group 2. The minimal linear epitope targeted by the mAb was ${ }^{433}$ NAELLVL ${ }^{439}$ in full length of HA and localized in the C-helix region of HA2 (residue 95-101, HA2 numbering). What's more, the mAb $3 \mathrm{C} 12$ inhibited $\mathrm{H} 1, \mathrm{H} 2, \mathrm{H} 5, \mathrm{H} 8, \mathrm{H} 9, \mathrm{H} 12, \mathrm{H} 13$ and $\mathrm{H} 16$ virus-replication in vitro and also has shown effectiveness in preventing and treating disease in mice challenged with lethal dose of AH/BRI99/16 (H9N2) virus in vivo. These results suggested that the broadly reactive anti-HA stem mAb 3C12 exhibited prophylactic and therapeutic efficacy.

Conclusions: Here, we have demonstrated that the linear epitope identified in this study could be a novel target for developing broad-spectrum influenza diagnostics or vaccine design, and the HA2-based monoclonal antibody is indeed a promising strategy for broad-spectrum protection against seasonal and pandemic influenza viruses.
\end{abstract}

Keywords: Influenza virus, HA2 stalk region antibody, Broad-spectrum, Epitope

*Correspondence: HT_z1@126.com; jihui.ping@njau.edu.cn

${ }^{1}$ MOE International Joint Collaborative Research Laboratory for Animal Health and Food Safety \& Jiangsu Engineering Laboratory of Animal Immunology, College of Veterinary Medicine, Nanjing Agricultural University, Nanjing 210095, China

${ }^{2}$ Biotechnology Research laboratory, Jiangsu Lihua Animal Husbandry co. LTD, Changzhou 213168, China

\section{Background}

Influenza viruses cause millions of cases of severe illness, thousands of deaths, and considerable economic losses each year [1]. According to the collecting data from World Health Organization (WHO), influenza A viruses (IAVs) annually cause about 3 to 5 million cases of severe illness and approximately 290,000 to 650,000 respiratory deaths worldwide [2]. Importantly, some avian influenza viruses have the potential to acquire mammalian transmissibility by reassortment, such as H5N1 [2]. And some 
vaccines against $\mathrm{H} 5 \mathrm{~N} 1$ viruses, including inactivated vaccines and live virus vectored vaccines were produced to protect the avian and human [3, 4]. IAVs possess eight segmented, negative-sense viral RNAs (vRNAs) as its genome. Two of these vRNAs encode hemagglutinin (HA) and neuraminidase (NA), which are major viral antigenic proteins on the virus particle [5]. HA is a trimer of HA1 and HA2 that is produced by cleavage of the precursor HA0 [6] and belongs to type I glycoprotein, which is the most abundant transmembrane protein on the surface of influenza viral particles [7]. On the basis of the two major surface antigenic proteins HA and NA, IAVs can be currently subtyped into $18 \mathrm{HA}$ and $11 \mathrm{NA}$ serotypes, respectively $[8,9]$. The HA1 subunit of HA mediates attachment of the virus to target cells through interactions with sialic acid receptors. After the virus was devoured, the low $\mathrm{pH}$ triggers conformational changes in HA2, leading to fusion of the viral and endosomal membranes, releasing the viral genome into the cytoplasm [1]. So far, some HA inhibitors that block the fusion of HA with endosome have already been generated, seen in the following list: CL-61917, CL-385319, and CL-62554 [10]; BMY-27709 [11]; RO5464466 and RO5487624 [12]; FA-583 and FA-617 [13] which target group 1 HAs; whereas TBHQ [14, 15], S19 and C22 [16] are fusion inhibitors to group 2 HAs. However, excessive use leads to resistant strains [17-19] that often show surprisingly little attenuation from the escape mutations. Considering the high variability and rapid microevolution of the influenza virus, vaccination remains the most effective countermeasure against influenza outbreak. Notably, current commercial vaccines of IAVs are still strain-specific and show only limited protective efficacy against the emerging strains with antigenic drift or shift $[20,21]$. Therefore, a broad-spectrum vaccine against all the 18 HA subtypes is highly required for protection against epidemics or pandemics of IAVs in both human and animals.

The HA2 subunit makes up the major part of the HA stalk region and is highly conserved within subtypes [22, 23]. Subsequently, some monoclonal antibodies owning heterosubtypic activity have already been generated. According to the reactivity, the HA2 target mAbs were divided into three types. The first type contains monoclonal antibodies that react with group 1; mAbs CR6261 [24, 25], F10 [26], 3.1 [27], FE43, FC41 [28], A06 [29] and PN-SIA49 [30] belong to the first type. The second type contains monoclonal antibodies CR8020 [1], CR8043 [31], 9H10 [32], 042-100,809-2F04 [33] and SD36 [34] that react with group 2 . The final type contains monoclonal antibodies reacted with both group 1 and group 2 including CR9114 [35]; FI6v3 [36], 39.29 and CT149 [37], PNSIA28 [38], VIS410 [39], MEDI8852 [40], 27F3 [41], S9-1-10/5-1 [5] and SD38 [34]. Furthermore, CR9114
[35] and 27F3 [41] could also react with the HA stem region of influenza $B$ virus.

Here, we generated a HA2-based monoclonal antibody named $3 \mathrm{C} 12$. The region recognized by $3 \mathrm{C} 12$ was localized to a conserved portion of the HA stem domain. $3 \mathrm{C} 12$ can react with a large amount of subtypes of group 1 viruses including $\mathrm{H} 1, \mathrm{H} 2, \mathrm{H} 5, \mathrm{H} 8, \mathrm{H} 9, \mathrm{H} 12$, H13, H16 and also HA protein of H18. Next, we mapped the epitope of $3 \mathrm{C} 12{ }^{95} \mathrm{NAELLVL}^{101}$ (HA2 numbering) located in the C-helix region following the loop of HA2. $3 \mathrm{C} 12$ could inhibit infection of MDCK cells from $\mathrm{H} 1, \mathrm{H} 2$, $\mathrm{H} 5, \mathrm{H} 8, \mathrm{H} 9, \mathrm{H} 12, \mathrm{H} 13$ and $\mathrm{H} 16$ viruses in vitro. Additionally, mAb $3 \mathrm{C} 12$ showed prophylactic and therapeutic efficacy in mouse models challenged with a lethal dose of AH/BRI99/16 (H9N2). Therefore, we demonstrated that the linear epitope identified in this study could be a novel target for developing broad-spectrum influenza diagnostics or vaccine candidates, and that the HA2-based monoclonal antibody is a promising strategy for broadspectrum protection against seasonal and pandemic influenza viruses.

\section{Methods \\ Viruses and plasmids}

The wild type or recombinant influenza viruses used in this study were as follows: A/duck/Alberta/35/76 (Alberta/35/76, H1N1), A/gull/Maryland/19/1977 (Maryland/19/77, H2N9), A/duck/Ukraine/1/1963 (Ukraine/1/63, H3N8), A/duck/Czechoslovakia/1956 (Czechoslovakia/56, H4N6), A/turkey/Wisconsin/1/1968 (Wisconsin/1/68, H5N9), A/turkey/ Massachusetts/3740/1965 (Massachusetts/3740/65, H6N2), A/turkey/Oregon/1971 (Oregon/71, H7N3), A/ turkey/Ontario/6118/1968 (Ontario/6118/68, H8N4), A/ chicken/Anhui/BRI99/2016 (AH/BRI99/16, H9N2), A/ chicken/Germany/N/1949 (Germany/N/49, H10N7), A/ duck/England/1/1956 (England/1/56, H11N6), A/duck/ Alberta/60/1976 (Alberta/60/76, H12N5), A/gull/Maryland/704/1977 (Maryland/704/77, H13N6), A/mallard/ Astrakhan/263/1982 (Astrakhan/263/82, H14N5), A/ shearwater/West Australia/2576/79 (Australia/2576/79, H15N9), A/black-headed gull/Sweden/5/99 (Sweden/5/99, H16N3), A/little yellow-shouldered bat/ Guatemala/164/2009 (Guatemala/164/09, H17N10), a/ flat-faced bat/ Peru/033/2010 (Peru/033/2010, H18N11), A/PuertoRico/8/1934 (PR8, H1N1), r-PR8+California/04/2009 (HA+NA) (r-PR8-Cal/04, H1N1), A/ WSN/1933 (WSN, H1N1), A/turkey/Wisconsin/1/1966 (Wisc/66, H9N2), A/chicken/Shandong/6/1996 (SD/6/96, H9N2), A/chicken/Guangxi/55/2005 (GX/55/05, H9N2), A/chicken/Guangdong/1/2010 (GD/1/10, H9N2), A/ chicken/Jiaxing/36/2013 (JX/36/13, H9N2), A/chicken/ Shandong/32/2015 (SD/32/15, H9N2), A/chicken/Anhui/ 
LH66/2017 (AH/66/17, H9N2), A/chicken/Changzhou/2/2019 (CZ/2/19, H9N2), B/Jiangsu/103/2015 (B/JS/103/15, Flu B). They were generated by reverse genetics or isolated from infected poultries and then inoculated into 10-day-old specific-pathogen-free (SPF) chicken embryos for virus propagation. The HA segment of $\mathrm{H} 17$ and $\mathrm{H} 18$ were synthesized (General Bio-systems, Anhui) and cloned into pCAGGS protein expressing vector.

\section{Cells}

Two hundred ninety-three $\mathrm{T}$ human embryonic kidney cells obtained from American Type Culture Collection (ATCC) were maintained in DMEM supplemented with $10 \%$ fetal bovine serum. Madin-Darby Canine Kidney (MDCK) cells (obtained from ATCC) were maintained in DMEM containing $10 \%$ new born calf serum.

\section{Virus rescue}

Virus rescues were performed as previously described by the twelve-plasmid reverse genetics system in a A/ Puerto Rico/8/1934 (PR8) backbone [42]. Briefly, $1 \mu \mathrm{g}$ of each protein expression plasmid (pCAGGS-WSNPB2, pCAGGS-WSN-PB1, pCAGGS-WSN-PA and pCAGGS-WSN-NP) and $0.2 \mu$ g of each viral RNA transcription plasmid (pHH21-PR8-PB2, pHH21-PR8-PB1, pHH21-PR8-PA, pHH21-PR8-NP, pHH21-PR8-NA, pHH21-PR8-M, pHH21-PR8-NS and pHH21-H1-HA to $\mathrm{pHH} 21-\mathrm{H} 16-\mathrm{HA}$ plasmid) were combined with $12 \mu \mathrm{l}$ Lipofectamine 2000 ( $2 \mu \mathrm{l}$ per $\mu \mathrm{g}$ DNA, Invitrogen), and the mixture was incubated at room temperature for 30 mins and then transferred to $80 \%$ confluent monolayers of $293 \mathrm{~T}$ cells in $35 \mathrm{~mm}$ dish. After $6 \mathrm{~h}$, the mixture was removed from the $293 \mathrm{~T}$ cells and replaced with OptiMEM (Gibco-BRL). Forty-eight hours after transfection, the culture medium was collected and inoculated into 10-day-old SPF chicken embryos for virus propagation.

\section{Expression of recombinant proteins}

The HA2 gene of AH/BRI99/16 (H9N2) was amplified by RT-PCR using the gene specific primers. Then the fragment was amplified with the specific program as follows: $5 \mathrm{~min}$ at $95^{\circ} \mathrm{C}$ for predenaturation; 35 cycles of $30 \mathrm{~s}$ at $95^{\circ} \mathrm{C}$ for denaturation, $30 \mathrm{~s}$ at $54^{\circ} \mathrm{C}$ for annealing, $1 \mathrm{~min}$ at $72^{\circ} \mathrm{C}$ for elongation; and finally, $10 \mathrm{~min}$ at $72^{\circ} \mathrm{C}$ for overall elongation. The obtained HA2 fragment was subcloned into the prokaryotic expression vector pET28a (Takara, Japan). The recombinant plasmid was verified by Sanger sequencing and then transformed into $E$. coli BL21 cells for the expression of HA2 protein. The expression of H9-HA2 protein including His tag was induced with $1 \mathrm{mM}$ isopropyl $\beta$-D-1- thiogalactopyranoside (IPTG), and the protein was purified using a Ni-NTA agarose (Thermo, USA) according to the manufacturer's instructions. The purified fusion protein was identified with SDS-PAGE and Western blot.

\section{Preparation of anti-HA2 protein monoclonal antibodies}

The mAbs were prepared as described in a previous study [43]. The recombinant $\mathrm{H} 9-\mathrm{HA} 2$ protein was used as the immunogen for the development of mAbs in this study. Briefly, six-week-old female BALB/c mice were injected subcutaneously with the mixture of $50 \mu \mathrm{g}$ of the purified recombinant HA2 protein and an equal volume of complete Freund's adjuvant (Sigma-Aldrich, USA). And the mice were intraperitoneally immunized with the mixture of the purified recombinant HA2 protein and an equal volume of incomplete Freund's adjuvant at $14 \mathrm{dpi}$ and $28 \mathrm{dpi}$. Three days after the last immunization, the mice were boosted with $100 \mu \mathrm{g}$ of the HA2 protein, the spleen cells of the best responder animals were harvested and fused with SP2/0 myeloma cells using polyethylene glycol 2000 (Sigma-Aldrich, USA) according to the manufacture's instruction. The fused cells were selected in hypoxanthine, aminopterin and thymidine (HAT) medium. The positive clones were screened by ELISA using the recombinant HA2 protein and were subcloned 4 times by limiting dilution. The mAbs against H9-HA2 were collected and purified from the mouse ascites, which injected with the positive hybridomas.

\section{Construction of the HA amino acid sequence dendrogram}

The HA genes of all H1-H18 subtypes used in this study were aligned by MegAlign (Clustal W Method) and beautified by iTOL website.

\section{Western blot}

MDCK cells were infected with the H1-H16 subtype corresponding recombinant viruses or $293 \mathrm{~T}$ cells were transfected with pCAGGS-H17HA or pCAGGS-H18HA plasmid. Cells were collected and lysed with NP-40 lysis buffer (Beyotime, Shanghai) after 24h' infection or transfection. Cell lysates were mixed with $4 \times$ loading buffer (Solarbio, Beijing) and denatured at $100^{\circ} \mathrm{C}$ for $15 \mathrm{~min}$, then were separated using SDS-PAGE with a $10 \%$ polyacrylamide gel [44] and transferred to NC membranes (GE Healthcare, Amersham). Next, membranes were blocked with $5 \%$ skimmed milk in PBS at $37^{\circ} \mathrm{C}$ f for $1 \mathrm{~h}$, then washed six times (5 min per time) with PBST and incubated with primary antibody $3 \mathrm{C} 12(1: 800)$ at $4{ }^{\circ} \mathrm{C}$ overnight. Then, after six times washing, the membrane was incubated with HRP-conjugated goat anti-mouse antibody (1:10000; KPL, Gaithersburg, MD) as secondary antibody at $37^{\circ} \mathrm{C}$ for $1 \mathrm{~h}$. Membranes were then washed and the target protein bands were detected with enhanced chemiluminescence (ECL) (Vazyme, Nanjing) 
and the signals were recorded using Image Lab Software (Bio-Rad). GADPH served as a loading control.

\section{Indirect immunofluorescence assay}

For the indirect immunofluorescence assay, $80 \%$ confluent MDCK cells in 12-well plate were inoculated with the viruses mentioned above at $\mathrm{MOI}=0.01$ at $37^{\circ} \mathrm{C}$ for $1 \mathrm{~h}$, then the virus inoculum was removed and replaced by cell maintenance medium with $1 \mu \mathrm{g} / \mathrm{ml}$ TPCK-trypsin and were incubated at $5 \% \mathrm{CO}_{2}, 37^{\circ} \mathrm{C}$ for $24 \mathrm{~h}$. In addition, the $70 \%$ confluent $293 \mathrm{~T}$ cells in 12 -well plate were transfected with 500 ng pCAGGS-H17 HA or pCAGGS-H18 HA plasmids for $24 \mathrm{~h}$. Then the infected MDCK cells or transfected $293 \mathrm{~T}$ cells were washed with PBS, fixed with $4 \%$ paraformaldehyde for 20 mins at room temperature, permeabilized with $0.2 \%$ Triton X-100 (Sigma-Aldrich, USA) in PBS for $15 \mathrm{~min}$, and then washed with PBS for three times. 5\% skimmed milk in PBS was then added to the desired wells for $30 \mathrm{mins}$ at $37^{\circ} \mathrm{C}$. Then, the cells were washed and stained with primary antibody $3 \mathrm{C} 12(1: 800)$ at $4{ }^{\circ} \mathrm{C}$ overnight. After six times washing, the cells were incubated with fluorescein isocyanate (FITC)-conjugated goat anti-mouse IgG (1:500; KPL, Gaithersburg, MD, USA) as secondary antibody at $37^{\circ} \mathrm{C}$ for $1 \mathrm{~h}$. Finally, images were acquired using fluorescent microscope (Nikon, Tokyo, Japan).

\section{Mapping of HA2 protein linear epitope}

To identify the precise epitopes of the HA2 protein targeted by 3C12, the HA gene of AH/BRI99/16 was truncated step by step. These truncated fragments of AH/BRI99/16 HA were amplified and cloned into the pCAGGS protein expressing vector. To verify whether the minimal amino acids were the shortest epitope, the gene of short peptides were amplified and cloned into the pGEX-4T-1 vector containing the GST tag and expressed in $E$. coli BL21 (DE3). Then, the truncated HA fragments and short peptides were transfected into $293 \mathrm{~T}$ cells, the cells were lysated or fixed at $24 \mathrm{~h}$ post-transfection and then incubated with $\mathrm{mAb} 3 \mathrm{C} 12$ for WB or IFA analysis.

\section{Alignment of HA2 protein epitope sequences}

The alignment of amino acid sequences of HA2 target epitope was performed by MEGA6 program.

\section{Micro-neutralization assay of $\mathrm{mAb} 3 \mathrm{C} 12$ in vitro}

To test the neutralization activity of $3 \mathrm{C} 12$, the $\mathrm{mAb}$ was 2-fold serial diluted in 96-well plates. One hundred $\mathrm{TCID}_{50}$ of corresponding viruses were mixed with diluted $3 \mathrm{C} 12$, then the mixture was incubated at $37^{\circ} \mathrm{C}$ for $1 \mathrm{~h}$. After that, the mixture was inoculated into $95 \%$ confluent MDCK cells in 96-well plates. After $1 \mathrm{~h}$ incubation, the infected MDCK cells were washed with PBS and then cultured in DMEM with $1 \mu \mathrm{g} / \mathrm{ml}$ TPCK-trypsin at $37^{\circ} \mathrm{C}$ for 3 days. After that the neutralizing titers were measured by hemagglutination assay (HA). The results were evaluated by the value of $\mathrm{IC}_{50}$.

\section{Evaluation of $\mathrm{mAb} 3 \mathrm{C} 12$ for its prophylactic and therapeutic protective activities in mice model}

To identify the prophylactic and therapeutic efficacy in mice, six to eight-week-old female BALB/c mice were used in this study. Mice were weighed the body weight on the day or 1 day before virus challenge and monitored daily until day 14 for weight loss and survival (mice with body weight loss of $\geq 25 \%$ were euthanized).

For the prophylactic efficacy study, five groups mice (five mice of each group) were intravenously injected with $\mathrm{mAb} 3 \mathrm{C} 12$ at a dose of $1 \mathrm{mg} / \mathrm{kg}, 5 \mathrm{mg} / \mathrm{kg}, 10 \mathrm{mg} / \mathrm{kg}$, $20 \mathrm{mg} / \mathrm{kg}$ in $50 \mu \mathrm{l}$ volume or PBS as a control. Three hours after $\mathrm{mAb}$ administration, all the mice were intranasally inoculated with $10 \mathrm{MLD}_{50}$ AH/BRI99/16 (H9N2) in $50 \mu \mathrm{l}$ volume. For the therapeutic efficacy study, seven groups mice (five mice per group) were intranasally inoculated with $10 \mathrm{MLD}_{50} \mathrm{AH} / \mathrm{BRI} 99 / 16$ (H9N2) virus, then the mice received $15 \mathrm{mg} / \mathrm{kg} \mathrm{mAb} 3 \mathrm{C} 12$ treatment intravenously (i.v.) on day $0,1,2,3,4,5$ days post-infection, or PBS treatment as control.

\section{Ethical statement}

The mice were handled humanely according to the rules described by the Animal Ethics Procedures and Guidelines of the People's Republic of China and Institutional Animal Care and Use Committee of Nanjing Agricultural University [SYXK(Su)2017-0007].

\section{Results}

Identification of monoclonal antibody binding to influenza A viruses of group 1

In this study, we generated several cross-reactive mouse monoclonal antibodies. One of which, named 3C12, could react with several different influenza A viruses. To identify exactly which HA subtypes could be recognized by mAb $3 \mathrm{C} 12$, influenza A viruses of subtypes $\mathrm{H} 1$ through $\mathrm{H} 16$ and HA proteins for $\mathrm{H} 17$ and $\mathrm{H} 18$ (because of failure of generation $\mathrm{H} 17$ and $\mathrm{H} 18$ recombinant viruses) were employed for reactivity testing. The different subtypes of influenza A viruses tested in this study were shown in a phylogenetic tree which separated into group 1 and group 2 (Fig. 1). The binding activity of the $\mathrm{mAb}$ was examined by western blot (WB) and indirect immunofluorescence assay (IFA). Both results showed that the $\mathrm{mAb}$ could react with many influenza subtypes. According to WB data (Fig. 2a), we found that $\mathrm{mAb} 3 \mathrm{C} 12$ was able to react with $\mathrm{H} 1, \mathrm{H} 2, \mathrm{H} 5, \mathrm{H} 8, \mathrm{H} 9, \mathrm{H} 12, \mathrm{H} 13$, H16 viruses and the H17, H18 HA proteins. The IFA data 


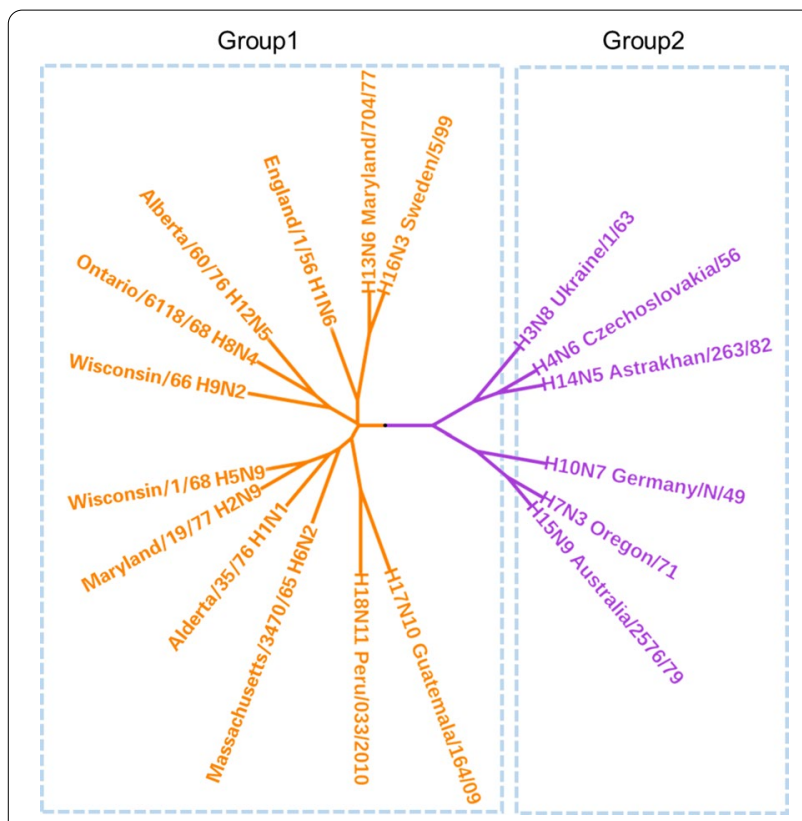

Fig. 1 The phylogenetic tree of the $\mathrm{H} 1-\mathrm{H} 18 \mathrm{HA}$ sequences tested in this study. The phylogenetic tree was made by the neighbor-joining method. Group 1 subtypes were shown in orange and group 2 subtypes in purple. They stood for the short name of the strains

largely confirmed the WB results, except for the H17 HA protein (Fig. 2b). These data suggested that $3 \mathrm{C} 12$ could react with a majority of viruses of group 1 , however, it did not react with any viruses of group 2 . The selected $\mathrm{mAb} 3 \mathrm{C} 12$ was also tested against a panel of human $\mathrm{H} 1 \mathrm{~N} 1$ viruses spanning more than 80 years, and H9N2 representatives strains of different antigenic groups. Specifically, PR8, WSN, and r-PR8-Cal/04 were chosen to represent $\mathrm{H} 1 \mathrm{~N} 1$ subtypes; $\mathrm{SD} / 6 / 96, \mathrm{GX} / 55 / 05, \mathrm{GD} / 1 / 10$, $\mathrm{JX} / 36 / 13, \mathrm{SD} / 32 / 15, \mathrm{AH} / 66 / 17$ and $\mathrm{CZ} / 2 / 19$ were chosen to represent $\mathrm{H} 9 \mathrm{~N} 2$ subtypes. Interestingly, the mAb $3 \mathrm{C} 12$ could react with all of these viruses (Fig. 2c).Detailed information about the viruses used in this study were shown in Table 1 . Summarizing the results above, the mAb $3 \mathrm{C} 12$ could not only react with numerous viruses of group 1, but also with various different isolates of $\mathrm{H} 1$ and H9 subtypes in different years with different antigenicity, including both North-American and Eurasian lineages of H9N2 strains.

\section{Mapping of the potential cross-protective epitope on HA protein}

To identify the target epitope of mAb $3 \mathrm{C} 12$, a series of truncated HA fragments of AH/BRI99/16 (H9N2) were constructed and the reaction activity was evaluated by WB. Based on the first round truncation, we found the $\mathrm{mAb}$ recognized the fragment $\mathrm{HA}_{388-490}\left(\mathrm{HA}_{50-152}\right)$ well. Following another round truncation, the $\mathrm{mAb}$ a WB

H1 H2 H3 H4 H5 H6 H7 H8 H9 H10 H11 H12 H13 H14 H15 H16 H17 H18

$$
\text { HA }
$$

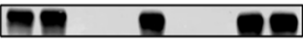

GADPH

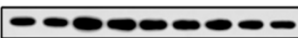

b IFA

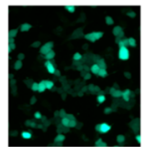

$\mathrm{r}-\mathrm{H} 1$
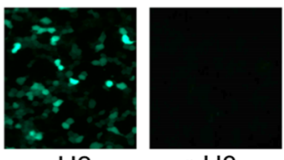

$\mathrm{r}-\mathrm{H} 2$
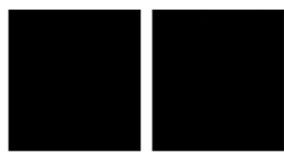

$\mathrm{r}-\mathrm{H} 3$

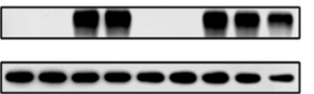

$\mathrm{r}-\mathrm{H} 6$
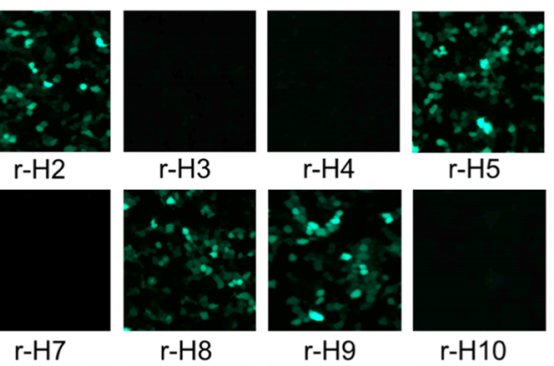

$\mathrm{r}-\mathrm{H} 5$
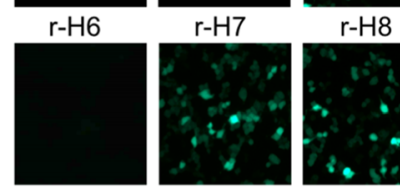

$\mathrm{r}-\mathrm{H} 9$

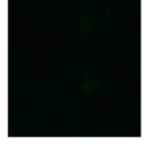

$-\mathrm{H} 11$
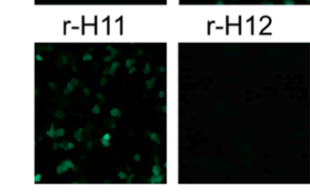

C

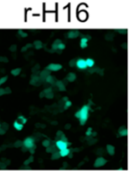

H17HA
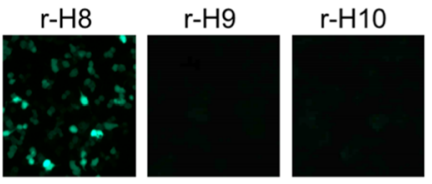

$\mathrm{r}-\mathrm{H} 13$

$\mathrm{r}-\mathrm{H} 14$
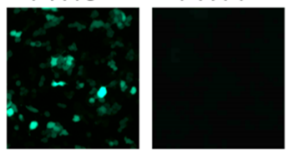

$\mathrm{r}-\mathrm{H} 15$

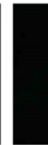

Flu B
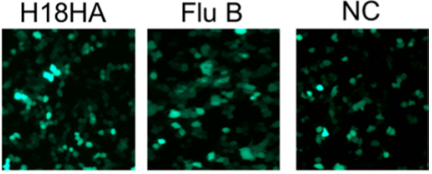

PR8

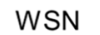

-PR8-Cal/04

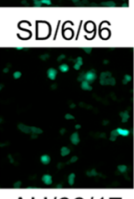

GX/55/05
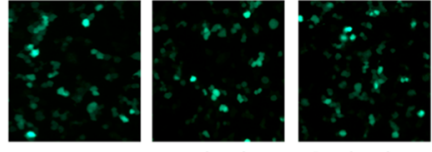

$\mathrm{JX} / 36 / 13 \quad \mathrm{SD} / 32 / 15$

$\mathrm{AH} / 66 / 17$

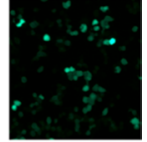

$\mathrm{CZ} / 2 / 19$

Fig. 2 The broad-spectrum neutralization of influenza viruses against mAb 3C12. a Western Blot (WB) analysis. The lysates of influenza virus $\mathrm{H} 1-\mathrm{H} 16$-infected MDCK cells and $\mathrm{H} 17$ and $\mathrm{H} 18 \mathrm{HA}$ protein transfected 293T cells were incubated with the mAb 3C12. b Indirect immunofluorescence assays (IFA). MDCK cells were infected with H1-H16 and flu B for no more than 24h, 293T cells were transfected with pCAGGS-H17 HA and $\mathrm{H} 18 \mathrm{HA}$ for $24 \mathrm{~h}$, and then the cells were fixed and incubated with mAb 3C12. c IFA. MDCK cells were infected with other strains of subtype $\mathrm{H} 1$ and $\mathrm{H} 9$. NC served as negative control

was confirmed to recognize the fragment $\mathrm{HA}_{430-442}$ $\left(\mathrm{HA} 2_{92-104}\right)$. After that, the truncated fragment was then shortened to HA2 $2_{95-101}$, and the WB data showed the ${ }^{95}$ NAELLVL ${ }^{101}$ (HA2 numbering) could still be bound by $3 \mathrm{C} 12$, see Fig. $3 \mathrm{a}$. Next, we were wondering to know if this polypeptide was the shortest target epitope, so the fragments $432-439$ aa $\left(\mathrm{HA} 2_{94-101}\right), 433-439$ aa $\left(\mathrm{HA} 2_{95-101}\right)$, 433-438 aa (HA2 $\left.{ }_{95-100}\right)$ of AH/BRI99/16 HA were cloned into the pGEX-4T-1 vector and expressed in 
Table 1 Names of viruses used in this article

\begin{tabular}{|c|c|c|}
\hline Subtype & Full name & Short name \\
\hline \multirow[t]{4}{*}{$\mathrm{H} 1$} & r-PR8-A/duck/Alberta/35/76 & Alberta/35/76 \\
\hline & A/Puerto Rico/8/1934 & PR8 \\
\hline & A/WSN/1933 & WSN \\
\hline & r-PR8-California/04/2009 & r-PR8-Cal/04 \\
\hline $\mathrm{H} 2$ & r-PR8-A/gull/Maryland/19/1977 & Maryland/19/77 \\
\hline $\mathrm{H} 3$ & r-PR8-A/duck/Ukraine/1/1963 & Ukraine/1/63 \\
\hline $\mathrm{H} 4$ & r-PR8-A/duck/Czechoslovakia/1956 & Czechoslovakia/56 \\
\hline H5 & r-PR8-A/turkey/Wisconsin/1/1968 & Wisconsin/1/68 \\
\hline $\mathrm{H} 6$ & r-PR8-A/turkey/Massachusetts/3740/1965 & Massachusetts/3740/65 \\
\hline $\mathrm{H7}$ & r-PR8-A/turkey/Oregon/1971 & Oregon/71 \\
\hline $\mathrm{H} 8$ & r-PR8-A/turkey/Ontario/6118/1968 & Ontario/6118/68 \\
\hline \multirow[t]{8}{*}{ H9 } & r-PR8-A/chicken/Anhui/BRI99/2016 & AH/BRI99/16 \\
\hline & r-PR8-A/chicken/Shandong/6/96 & SD/6/96 \\
\hline & r-PR8-A/chicken/Guangxi/55/2005 & GX/55/05 \\
\hline & r-PR8-A/chicken/Guangdong/1/2010 & $\mathrm{GD} / 1 / 10$ \\
\hline & r-PR8-A/chicken/Jiangxi/36/2013 & $J X / 36 / 13$ \\
\hline & r-PR8-A/chicken/Shandong/32/2015 & $\mathrm{SD} / 32 / 15$ \\
\hline & r-PR8-A/chicken/Anhui/LH66/2017 & $\mathrm{AH} / 66 / 17$ \\
\hline & A/chicken/Changzhou/2019 & $\mathrm{CZ} / 2 / 19$ \\
\hline $\mathrm{H} 10$ & r-PR8-A/chicken/Germany/N/1949 & Germany/N/49 \\
\hline $\mathrm{H} 11$ & r-PR8-A/duck/England/1/1956 & England/1/56 \\
\hline $\mathrm{H} 12$ & r-PR8-A/duck/Alberta/60/1976 & Alberta/60/76 \\
\hline $\mathrm{H} 13$ & r-PR8-A/gull/Maryland/704/1977 & Maryland/704/77 \\
\hline $\mathrm{H} 14$ & r-PR8-A/mallard/Astrakhan/263/1982 & Astrakhan/263/82 \\
\hline $\mathrm{H} 15$ & r-PR8-A/shearwater/West Australia/2576/79 & Australia/2576/79 \\
\hline $\mathrm{H} 16$ & r-PR8-A/black-headed gull/Sweden/5/99 & Sweden/5/99 \\
\hline $\mathrm{H} 17$ & A/little yellow-shouldered bat/Guatemala/164/2009 & Guatemala/164/09 \\
\hline $\mathrm{H} 18$ & A/flat-faced bat/Peru/033/2010 & Peru/033/10 \\
\hline
\end{tabular}

(See figure on next page.)

Fig. 3 Analysis of the HA2 protein linear epitopes using WB and IFA. a Schematic representation of the HA truncated fragments used for epitope mapping (left). The corresponding results of WB were shown in right and the reactive fragments were containing ${ }^{433} \mathrm{NAELLVL}^{439}$ (or ${ }^{95} \mathrm{NAELLVL}{ }^{101}$, HA2 numbering) sequence in full length of HA. b The minimal epitope mapping of 3C12 using WB. The 433-439aa sequences was cloned into pGEX-4T-1 vector and expressed in E. coli BL21 then subjected to incubation with mAb 3C12. c Reaction of the mAb with the minimal epitope were evaluated by IFA. The three epitopes were cloned into PCAGGS vector and transfected into 293T cells, respectively. $\mathbf{d}$ The location of the epitope recognized by $3 \mathrm{C} 12$ in the HA molecule was determined by PyMOL using the PDB 1jsd (H9N2 HA). The corresponding positions were colored and pointed out with lines. Since the Alanine residue of the position 96 (HA2) did not exist on the surface, we could not map it. All the residues were represented by HA2 numbering. e The structure of HA molecule showed by cartoon using the PDB 1jsd. HA with helicx A (red), C (yellow), and D (blue) and B loop (orange) in one monomer colored distinctly

E. coli BL21 (DE3), then the reactivity was verified by WB (Fig. 3b). Furthermore, the fragment $\mathrm{HA} 2_{95-101}$ aa was also cloned into pCAGGS expressing vector and transfected $293 \mathrm{~T}$ cells to identify the fluorescent through IFA (Fig. 3c). Both WB and IFA results demonstrated $\mathrm{mAb}$ $3 \mathrm{C} 12$ bound to the ${ }^{95} \mathrm{NAELLVL}^{101}$ (HA2 numbering) epitope. The localization of the epitope recognized by the mAb was highlighted in the three-dimensional (3D) structure of HA protein (Fig. 3d). Since the 94A residue is not on the HA surface, it could not be represented. The epitope was displayed in cartoon format to identify the specific region recognized by the mAb. The epitopes of many previously studies showed that HA2-based mAbs were mainly located in fusion peptide and helix A region. Encouragingly, we found that the epitope was located in the relatively conserved C-helix region of HA2 (Fig. 3e). 
Round 1 $\left[\begin{array}{l}H A_{1-388} \\ H A_{1-442} \\ H A_{1-490} \\ H A_{\text {Full }}\end{array}\right.$

Round 2 $\left[\begin{array}{l}\mathrm{HA}_{1-388} \\ \mathrm{HA}_{1-410} \\ \mathrm{HA}_{1-420} \\ \mathrm{HA}_{1-430} \\ \mathrm{HA} \mathrm{A}_{1-442}\end{array}\right.$

Round 3

$\left[\begin{array}{l}\mathrm{HA}_{1-430} \\ \mathrm{HA}_{1-433} \\ \mathrm{HA}_{1-439} \\ \mathrm{HA}\end{array}\right.$

HA1
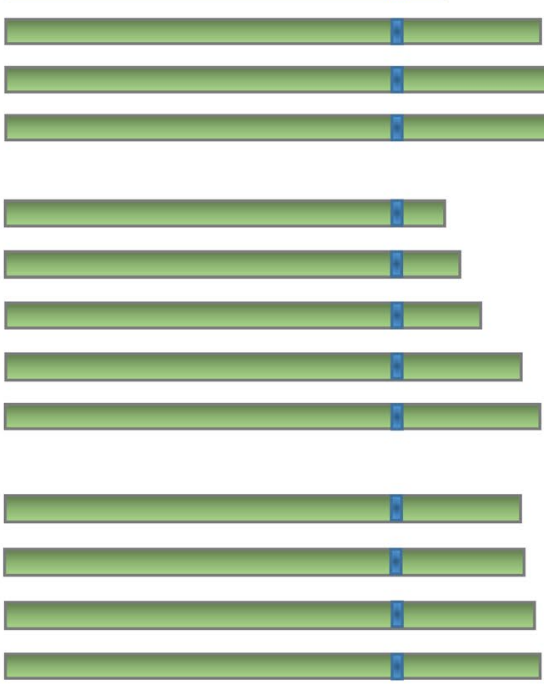

b

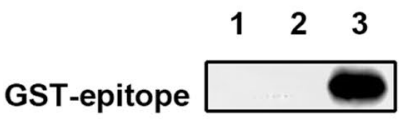

GADPH

$$
\infty-\infty
$$

Lane1: $\mathrm{HA}_{434-439}$ (pGEX-4T-1- ${ }_{434} \mathrm{AELLVL}_{439}$ )

Lane2: $\mathrm{HA}_{433-438}$ (pGEX-4T-1-NAELLV)

Lane3: $\mathrm{HA}_{433-439}$ (pGEX-4T-1-NAELLVL)

d
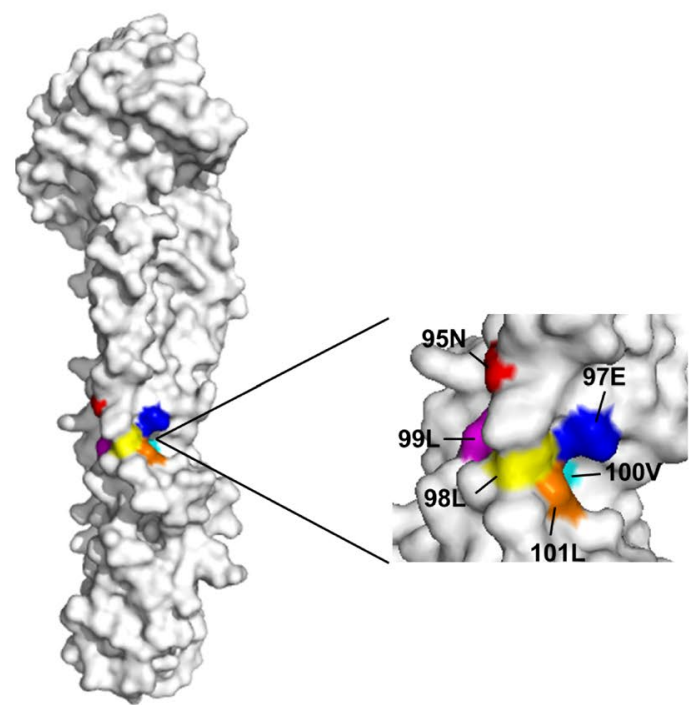

e
C

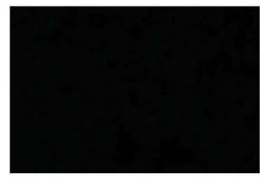

pCAGGS-AELLVL

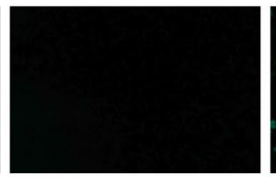

pCAGGS-NAELLV

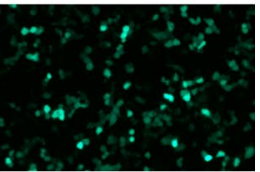

pCAGGS-NAELLVL
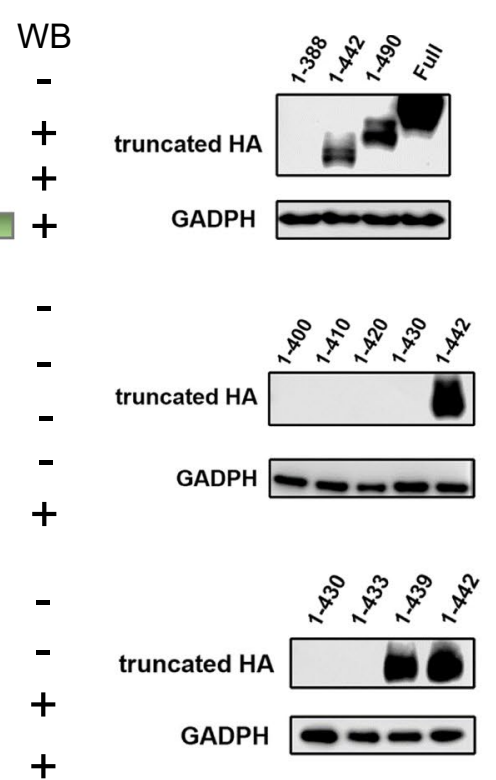

d

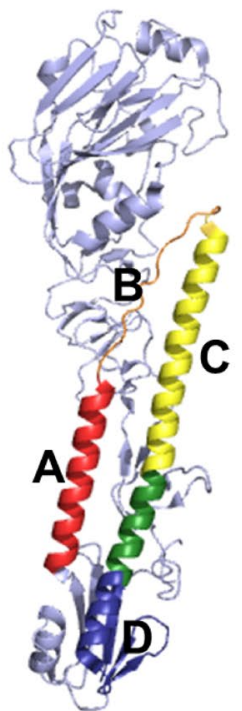




\section{Alignment of HA protein epitope sequences and its structure}

Influenza A viruses can be separated into two phylogenetic groups according to the sequence characteristic of HA2, known as group 1 and group 2. So, we next explored the reason why mAb $3 \mathrm{C} 12$ was able to recognize the subtypes in group 1, but not the subtypes of group 2. Firstly, we analyzed the reason for the HA2 liner sequence level. Through alignment of the HA2 gene sequences from $\mathrm{H} 1-\mathrm{H} 18$ subtypes, we found that the epitope ${ }^{95}$ NAELLVL ${ }^{101}$ (HA2 numbering) is quite conserved in the majority of subtypes of group 1 . In contrast, the HA subtypes of group 2 are all ${ }^{95} \mathrm{NAELLVA}^{101}$ (HA2 numbering) except $\mathrm{H} 10$, which deviates from the group at N95Q (HA2 numbering) (Fig. 4a). Given this, we speculated that L101A (HA2 numbering) eliminated the binding of the $\mathrm{mAb}$ with mutant epitopes, limiting its reactivity across groups. In those group 1 subtypes without mAb $3 \mathrm{C} 12$ reactivity, including $\mathrm{H} 6, \mathrm{H} 11$ and $\mathrm{H} 17$, the single mutation of E97Q (HA2 numbering) or A96T (HA2 numbering) may alter the epitope recognition. It is surprisingly that the epitope of $\mathrm{H} 6 \mathrm{HA}$ was the same as the sequence of $\mathrm{H} 9 \mathrm{HA}$, but the mAb $3 \mathrm{C} 12$ did not react with the H6 strain we selected in this study. Moreover, there may be other residues in HA2 protein that blocked its reactivity. Next, we investigated the protein trimeric structure differences among these subtypes. Interestingly, the $\mathrm{C}$-helix region was partly located in the interior of HA trimer. And the structure of H1, H3, H5 and H9 subtypes were presented in Fig. 4b.

\section{Micro-neutralization assay of the $3 \mathrm{C} 12 \mathrm{mAb}$ in vitro}

To evaluate the effect of preventing infection of $3 \mathrm{C} 12$ in vitro, we measured its neutralization ability with $\mathrm{H} 1-\mathrm{H} 16$ recombinant viruses in MDCK cells. According to the results shown in Table 2, it can be seen that $\mathrm{mAb} 3 \mathrm{C} 12$ has the strongest inhibition ability with a half maximal inhibitory concentration $\left(\mathrm{IC}_{50}\right)$ value of $17.4 \mu \mathrm{g} /$ $\mathrm{ml}$ against AH/BRI99/16 (H9N2) and Alberta/60/76 (H12) viruses. It has intermediate levels of inhibitory ability against $\mathrm{H} 2, \mathrm{H} 13, \mathrm{H} 16$ and two hererologous H9N2 viruses, and low inhibitory ability against $\mathrm{H} 1, \mathrm{H} 5$ and $\mathrm{H} 8$ viruses. Unfortunately, the $3 \mathrm{C} 12 \mathrm{mAb}$ didn't show any neutralization ability against group 2 influenza A viruses (Table 2).

\section{Prophylactic and therapeutic efficacy of $3 \mathrm{C} 12 \mathrm{mAb}$ in vivo}

To evaluate the prophylactic and therapeutic efficacy of $\mathrm{mAb} 3 \mathrm{C} 12$, the grouped mice were injected with $3 \mathrm{C} 12$ antibody and then challenged with lethal doses of recombinant virus or vice versa. In a prophylactic model, $5 \mathrm{mg} / \mathrm{kg} \mathrm{mAb} 3 \mathrm{C} 12$ could fully protect mice from lethal

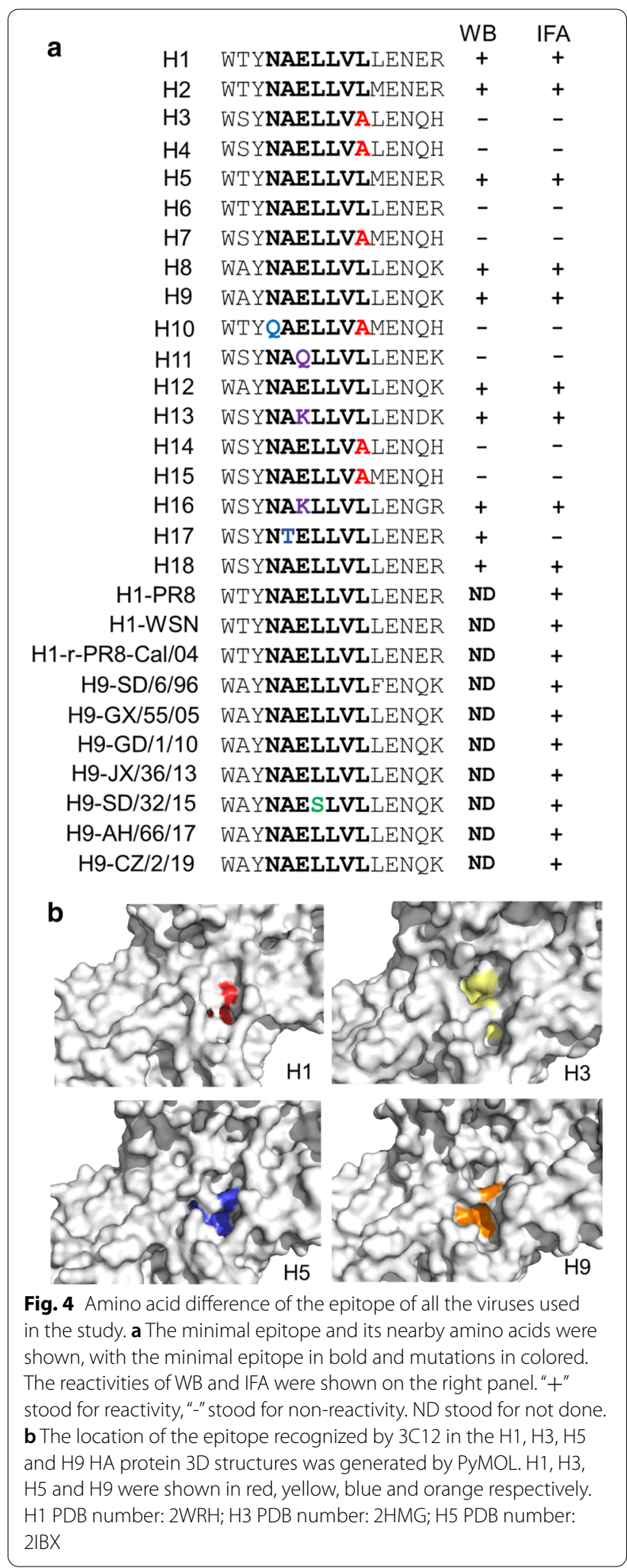


Table 2 Micro-neutralization activity of the mAb $3 C 12$

\begin{tabular}{|c|c|c|c|}
\hline Group & Subtype & Virus name & $\mathrm{I} \mathrm{C}_{50}(\mu \mathrm{g} / \mathrm{ml})$ \\
\hline \multirow[t]{12}{*}{ Group 1} & $\mathrm{H} 1$ & rPR8-A/duck/Alberta/35/76 & 52.1 \\
\hline & $\mathrm{H} 2$ & rPR8-A/gull/Maryland/19/1977 & 34.7 \\
\hline & $\mathrm{H} 5$ & rPR8-A/turkey/Wisconsin/1/1968 & 52.1 \\
\hline & $\mathrm{H} 6$ & $\begin{array}{l}\text { rPR8-A/turkey/Massachu- } \\
\text { setts/3740/1965 }\end{array}$ & ND \\
\hline & $\mathrm{H} 8$ & rPR8-A/turkey/Ontario/6118/1968 & 52.1 \\
\hline & \multirow[t]{3}{*}{ H9 } & rPR8-A/chicken/Anhui/BRI99/2016 & 17.4 \\
\hline & & rPR8-A/chicken/Guangdong/1/2010 & 34.7 \\
\hline & & rPR8-A/chicken/Shandong/32/2015 & 34.7 \\
\hline & $\mathrm{H} 11$ & rPR8-A/duck/England/1/1956 & ND \\
\hline & $\mathrm{H} 12$ & rPR8-A/duck/Alberta/60/1976 & 17.4 \\
\hline & $\mathrm{H} 13$ & rPR8-A/gull/Maryland/704/1977 & 34.7 \\
\hline & $\mathrm{H} 16$ & $\begin{array}{l}\text { rPR8-A/black-headed gull/Swe- } \\
\text { den/5/1999 }\end{array}$ & 34.7 \\
\hline \multirow[t]{6}{*}{ Group 2} & $\mathrm{H} 3$ & rPR8-A/duck/Ukraine/1/1963 & ND \\
\hline & $\mathrm{H} 4$ & rPR8-A/duck/Czechoslovakia/1956 & ND \\
\hline & $\mathrm{H7}$ & rPR8-A/turkey/Oregon/1971 & ND \\
\hline & $\mathrm{H} 10$ & rPR8-A/chicken/Germany/N/1949 & ND \\
\hline & $\mathrm{H} 14$ & rPR8-A/mallard/Astrakhan/263/1982 & ND \\
\hline & $\mathrm{H} 15$ & $\begin{array}{l}\text { rPR8-A/shearwater/West Aus- } \\
\text { tralia/2576/79 }\end{array}$ & ND \\
\hline
\end{tabular}

ND not detection

infection (Fig. 5a), which consistent with the absence of any signs of respiratory distress in mice. However, the mice that received PBS rapidly lost weight, showed signs of respiratory distress, and succumbed to infection or were euthanized when mice had lost $25 \%$ of their body weight. While verifying the therapeutic efficiency, at a dose of $15 \mathrm{mg} / \mathrm{kg} \mathrm{mAb} 3 \mathrm{C} 12$ was able to completely prevent mortality when administered on day 1 and 2 post-infection with $10 \mathrm{MLD}_{50}$ AH/BRI99/16 (H9N2) challenge (Fig. 5b). The same dose $\mathrm{mAb}$ treatment on day 3 post-infection shown $60 \%$ protective efficiency in mice. Though therapeutic treatment did not prevent morbidity, as illustrated by the initial weight loss, all mice in these treatment groups regained and even exceeded their original body weight by the end of the 14 days observation period.

\section{Discussion}

Similarly, H9N2 can cause human infections and may pose a severe public health threat, and attention needs to be paid for the pandemic preparedness [45]. Researchers have demonstrated that the widespread dissemination of H9N2 viruses poses a threat to human health not only because of the potential of these viruses to cause an influenza pandemic, but also because they can function as "vehicles" to deliver different subtypes of influenza viruses from avian species to humans [46]. The HA protein of influenza A virus serves as the primary target for neutralizing antibody production [44, 47], thus it is the most important antigen in IAVs. Traditionally, influenza vaccines mainly elicit strain-specific neutralizing antibodies against HA protein but generally show inefficient protection against newer strains due to antigenic drift or shift [20,48]. To overcome the deficiency of these influenza vaccines, the development of broadly protective vaccines against multiple or all subtypes of IAVs is a desirable strategy. It is well established that the stem region of the HA protein is relatively conserved among all subtypes of IAVs. Properly leveraging this knowledge could lead to the development of a single vaccine that protects against most or all subtypes of IAVs. The first heterosubtypic monoclonal antibody isolated, C179, was elicited by hyperimmunization of mice with an H2N2expressing human virus around 20 years ago [49]. Since then, a great many vaccine candidates with heterosubtypic activity have been generated, as described in the introduction section.

The broadly neutralizing antibodies generated against IAVs were comprehensively reviewed by Corti, et al. [50]. And the structural design of small proteins and peptides against the HA was comprehensively reviewed by Wu and Wilson [51]. Here, we produced a subtype cross-reactive monoclonal antibody $3 \mathrm{C} 12$, which was generated from an immortalized hybridoma cell line isolated following immunization of mice with bacterially-produced HA2 protein of AH/BRI99/16 (H9N2) virus. To identify the characteristics of this $\mathrm{mAb}$, a series of experiments were performed in this study. We demonstrated that a linear neutralizing epitope ${ }^{95}$ NAELLVL ${ }^{101}$ (HA2 numbering) in the C-helix region of HA protein could be efficiently recognized by $\mathrm{mAb} 3 \mathrm{C} 12$. Compared with those antibodies have been produced in other literatures, this is the first linear cross-reactive epitope located in the $\mathrm{C}$-helix region of HA2.

The above results indicated that $\mathrm{mAb} 3 \mathrm{C} 12$ could react with a majority of subtypes of group 1 including $\mathrm{H} 1, \mathrm{H} 2$, $\mathrm{H} 5, \mathrm{H} 8, \mathrm{H} 9, \mathrm{H} 12, \mathrm{H} 13, \mathrm{H} 16$ viruses and also the $\mathrm{H} 18$ $\mathrm{HA}$ protein. Interestingly, the H17 HA protein could react with $3 \mathrm{C} 12$ in WB but not in IFA, suggesting the targeting epitope of $\mathrm{H} 17$ protein might have a different three-dimensional conformation compare to other HA proteins in group 1 . In addition to this, $3 \mathrm{C} 12$ also couldn't react with the tested H6 strain, A/turkey/Massachusetts/3740/1965 (Massachusetts/3740/65, H6N2), in WB and IFA experiments, even though it shared the exact same linear sequence of HA2 from 95 to 101 (HA2 numbering) with other subtypes in group 1 . We speculated that there might be other amino acids around this epitope spatially block the reactivity, but the specific residues and the underlying mechanism need further exploration. It 


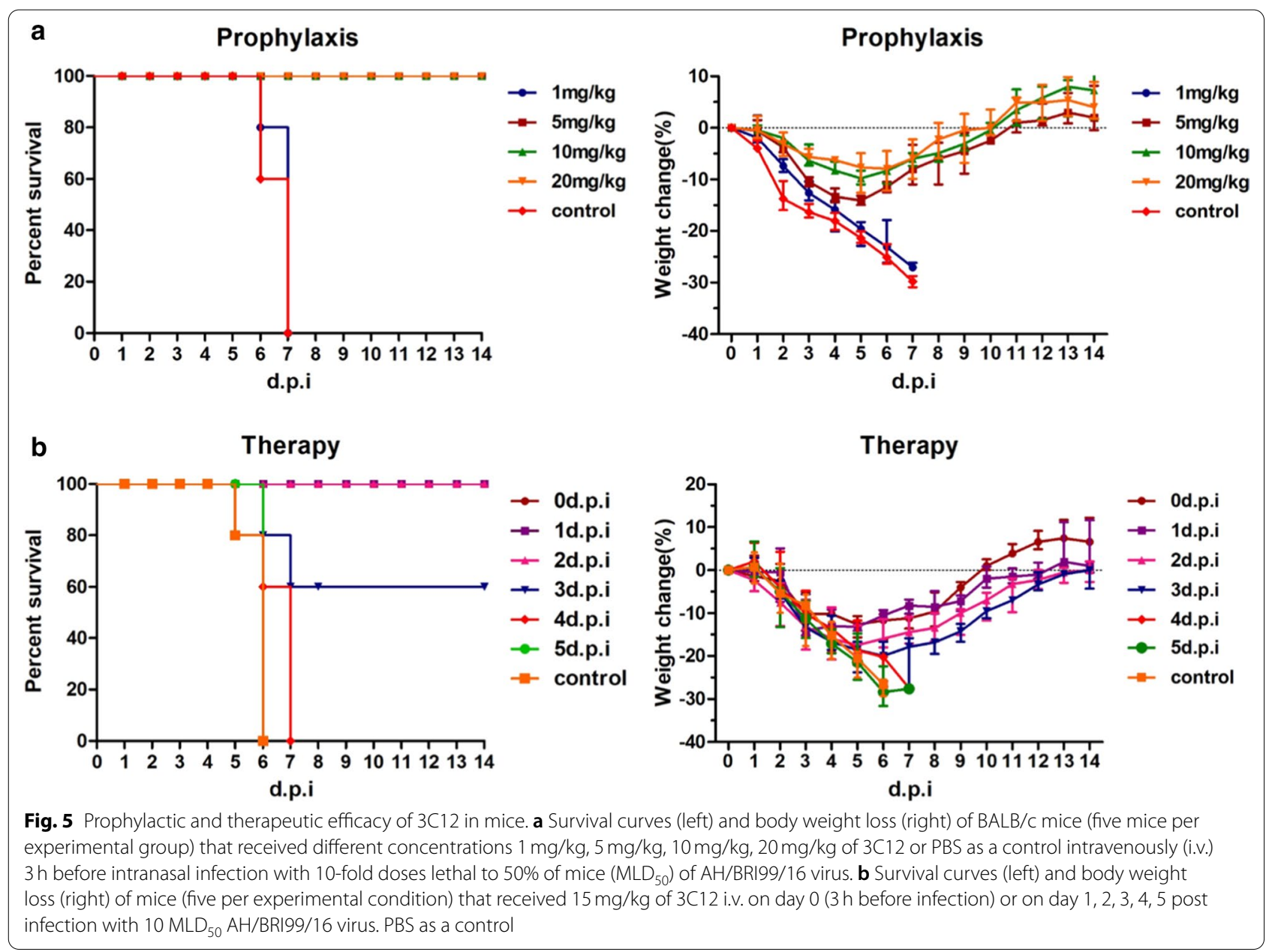

is disappointing that the $\mathrm{mAb}$ does not react with subtypes of group 2. Modifications on this epitope may provide new ideas for the design of monoclonal antibodies to attain the cross-group reactivity as an influenza vaccine candidate in the future. To our knowledge, the identified linear neutralizing epitope located in the $\mathrm{C}$-helix region of HA2 was partly in the internal of HA trimer. Indeed, a majority of cross-reactive HA mAbs, such as CR6261 [24, 25] and CR9114 [35],mainly recognize the fusion peptide and helix A region from the stem of HA. Therefore, our research might provide a novel region for generating broad-spectrum influenza vaccine candidates. Moreover, we found that in vitro $3 \mathrm{C} 12$ could inhibit the replication of most influenza subtypes of group 1, as measured by micro-neutralization assay in vitro. This mAb also had prophylactic and therapeutic protective activities in vivo. However, whether $3 \mathrm{C} 12$ has similar protective efficacy against other subtypes in group 1 needs further investigation.

Similarly, the FluA-20 was a broadly protective and naturally occurring human Ab. Researchers have demonstrated that the epitope which FluA-20 recognized was located in the internal of HA trimer, but it can reacted with nearly all subtypes of IAVs except for H16. The mechanism was that FluA-20 bond to the HA trimer interface and blocking cell-to-cell spread [52]. Another study reported the identification of three non-neutralizing but protective human $\mathrm{Abs}$ to $\mathrm{H} 1$ and $\mathrm{H} 3$ that bound to monomeric but not trimeric forms of HA [53]. In this study, the mechanism under the broad-spectrum activity of $3 \mathrm{C} 12$ had not been conducted. However, the two studies may provide some useful information to our following research.

\section{Conclusions}

In this study, we confirmed that the broadly reactive monoclonal antibody $3 \mathrm{C} 12$ suppressed the replication of most of subtypes on group 1 in vitro and tested H9N2 subtype in vivo. This indicates that the broadly neutralizing antibody $3 \mathrm{C} 12$ may contribute to the development of therapies against H9N2 strains, and could prove effective protection against emerging strains of pathogenic 
H9. Furthermore, it has the potential to become a broadspectrum influenza vaccine candidate against other IAVs in group 1 as suggested by the results of in vitro test. The novel HA2 C-helix epitope recognized by mAb 3C12 may become a new target region for the design of broad-spectrum monoclonal antibodies in the future and the underlying mechanism needed to be investigated in the near future.

\begin{abstract}
Abbreviations
WHO: World Health Organization; IAVs: Influenza A viruses; HA: Hemagglutinin; NA: Neuraminidase; MDCK: Madin-Darby canine kidney cells; ATCC: American Type Culture Collection; mAbs: monoclonal antibodies; MOl: Multiplicity of infection; $\mathrm{IC}_{50}: 50 \%$ Inhibitory concentration; $\mathrm{TCID}_{50}: 50 \%$ tissue culture infectious dose; iTOL: Interaction tree of life.
\end{abstract}

\section{Acknowledgments}

We thank Robert Presler for scientific editing, Dr. Yoshihiro Kawaoka (University of Wisconsin-Madison) for the gifts of the pHH21 and pCAGGS vectors, and Dr. Earl G Brown (University of Ottawa) for the gifts of "eight-plasmids" reverse genetics system of $A / P R / 8 / 34$ virus.

\section{Authors' contributions \\ Designed experiments and critically revised the manuscript: JH, NH, HZ, JP. Performed experiments: JH, NH, LZ, YL, PD. Analyzed data: JH, QL, YZ, MT. Drafted manuscript: MF, YG, JZ. Review \& editing: JH and JP. All authors read and approved the final manuscript.}

\section{Funding}

This work was supported by National Key Research and Development Program of China (Grant number: 2016YFD0500206), National Natural Science Foundation of China (Grant number: 31772775), the Specialized Fund for the Basic Research Operating Expenses Program of Central College (Grant number: KYZ201726) and the Priority Academic Program Development of Jiangsu Higher Education Institutions (PAPD).

\section{Availability of data and materials}

All relevant information is provided in this current manuscript. If required, the data presented in this work can be shared by e-mail.

\section{Ethics approval and consent to participate}

The animal study was reviewed and approved by the Nanjing Agricultural University Experimental Animal Welfare Ethics Committee with the approval ID is SYXK2017-0007.

\section{Consent for publication}

All authors consent to publication.

\section{Competing interests}

The authors declare that they have no competing interests.

Received: 22 October 2020 Accepted: 23 November 2020

Published online: 07 December 2020

\section{References}

1. Ekiert DC, Friesen RHE, Bhabha G, Kwaks T, Jongeneelen M, Yu W, Ophorst C, Cox F, Korse HJWM, Brandenburg B, et al. A highly conserved neutralizing epitope on group 2 influenza a viruses. Science. 2011;333:843-50.

2. Zhang Y, Zhang Q, Kong H, Jiang Y, Gao Y, Deng G, Shi J, Tian G, Liu L, Liu J, et al. H5N1 hybrid viruses bearing 2009/H1N1 virus genes transmit in Guinea pigs by respiratory droplet. Science. 2013;340:1459-63.

3. Li C, Bu Z, Chen H. Avian influenza vaccines against $\mathrm{H} 5 \mathrm{~N} 1$ 'bird flu'. Trends Biotechnol. 2014;32:147-56.
4. Chen H. H5N1 avian influenza in China. Sci China C Life Sci. 2009;52:419-27.

5. Yamayoshi S, Uraki R, Ito M, Kiso M, Nakatsu S, Yasuhara A, Oishi K, Sasaki T, Ikuta K, Kawaoka Y. A broadly reactive human anti-hemagglutinin stem monoclonal antibody that inhibits influenza a virus particle release. EBioMedicine. 2017;17:182-91.

6. Bommakanti G, Lu X, Citron MP, Najar TA, Heidecker GJ, ter Meulen J, Varadarajan R, Liang X. Design of Escherichia coli-expressed stalk domain immunogens of $\mathrm{H} 1 \mathrm{~N} 1$ hemagglutinin that protect mice from lethal challenge. J Virol. 2012;86:13434-44.

7. Zhang Y, Xu C, Zhang H, Liu GD, Xue C, Cao Y. Targeting hemagglutinin: approaches for broad protection against the influenza A virus. Viruses. 2019;11:405.

8. Tong S, Li Y, Rivailler P, Conrardy C, Castillo DA, Chen LM, Recuenco S, Ellison JA, Davis CT, York IA, et al. A distinct lineage of influenza a virus from bats. Proc Natl Acad Sci U S A. 2012;109:4269-74.

9. Tong S, Zhu X, Li Y, Shi M, Zhang J, Bourgeois M, Yang H, Chen X, Recuenco S, Gomez J, et al. New World Bats Harbor diverse influenza a viruses. Plos Pathog. 2013;9:e1003657.

10. Plotch SJ, O'Hara B, Morin J, Palant O, LaRocque J, Bloom JD, Lang SA, DiGrandi MJ, Bradley M, Nilakantan R, Gluzman Y. Inhibition of influenza a virus replication by compounds interfering with the Fusogenic function of the viral hemagglutinin. JVirol. 1999;73:140-51.

11. Luo G, Colonno R, Krystal M. Characterization of a hemagglutinin-specific inhibitor of influenza a virus. Virology. 1996;226:66-76.

12. Zhu L, Li Y, Li S, Li H, Qiu Z, Lee C, Lu H, Lin X, Zhao R, Chen L, et al. Inhibition of influenza a virus ( $\mathrm{H} 1 \mathrm{~N} 1)$ fusion by benzenesulfonamide derivatives targeting viral hemagglutinin. PLoS One. 2011;6:e29120.

13. Lai KK, Cheung NN, Yang F, Dai J, Liu L, Chen Z, Sze KH, Chen HL, Yuen KY, Kao RY. Identification of Novel Fusion Inhibitors of Influenza A Virus by Chemical Genetics. J Virol. 2015;90:2690-701.

14. Russell RJ, Kerry PS, Stevens DJ, Steinhauer DA, Martin SR, Gamblin SJ, Skehel JJ. Structure of influenza hemagglutinin in complex with an inhibitor of membrane fusion. Proc Natl Acad Sci. 2008;105:17736-41.

15. Bodian DL, Yamasaki RB, Buswell RL, Stearns JF, White JM, Kuntz ID. Inhibition of the fusion-inducing conformational change of influenza hemagglutinin by benzoquinones and hydroquinones. Biochemistry. 1993:32:2967-78.

16. Hoffman LR, Kuntz ID, White JM. Structure-based identification of an inducer of the low-pH conformational change in the influenza virus hemagglutinin: irreversible inhibition of infectivity. J Virol. 1997;71:8808-20.

17. Anice $C L$, Peter P. Influenza virus transmission: basic science and implications for the use of antiviral drugs during a pandemic. Infect Disord Drug Targets. 2007;7:318-28.

18. Bright RA, Shay DK, Shu B, Cox NJ, Klimov Al. Adamantane Resistance Among Influenza A Viruses Isolated Early During the 2005-2006 Influenza season in the United States. JAMA. 2006;295:891-4.

19. Kiso M, Mitamura K, Sakai-Tagawa Y, Shiraishi K, Kawakami C, Kimura K, Hayden FG, Sugaya N, Kawaoka Y. Resistant influenza a viruses in children treated with oseltamivir: descriptive study. Lancet. 2004;364:759-65.

20. Russell CA, Jones TC, Barr IG, Cox NJ, Garten RJ, Gregory V, Gust ID, Hampson AW, Hay AJ, Hurt AC. The global circulation of seasonal influenza a (H3N2) viruses. Science. 2008;320:340-6.

21. Lee JKH, Lam GKL, Shin T, Kim J, Krishnan A, Greenberg DP, Chit A. Efficacy and effectiveness of high-dose versus standard-dose influenza vaccination for older adults: a systematic review and meta-analysis. Expert Rev Vaccin. 2018;17:435-43.

22. Fouchier RA, Munster V, Wallensten A, Bestebroer TM, Herfst S, Smith D, Rimmelzwaan GF, Olsen B, Osterhaus AD. Characterization of a novel influenza a virus hemagglutinin subtype $(\mathrm{H} 16)$ obtained from blackheaded gulls. J Virol. 2005;79:2814-22.

23. Raymond DD, Bajic G, Ferdman J, Suphaphiphat P, Settembre EC, Moody MA, Schmidt AG, Harrison SC. Conserved epitope on influenza-virus hemagglutinin head defined by a vaccine-induced antibody. Proc Natl Acad Sci. 2018;115:168-73.

24. Ekiert DC, Bhabha G, Elsliger M-A, Friesen RHE, Jongeneelen M, Throsby $M$, Goudsmit J, Wilson IA. Antibody recognition of a highly conserved influenza virus epitope. Science. 2009;324:246-51.

25. Throsby M, van den Brink E, Jongeneelen M, Poon LL, Alard P, Cornelissen L, Bakker A, Cox F, van Deventer E, Guan Y, et al. Heterosubtypic 
neutralizing monoclonal antibodies cross-protective against H5N1 and $\mathrm{H} 1 \mathrm{~N} 1$ recovered from human IgM+ memory B cells. Plos One. 2008;3:e3942.

26. Sui J, Hwang WC, Perez S, Wei G, Aird D, Chen LM, Santelli E, Stec B, Cadwell $G$, Ali M, et al. Structural and functional bases for broad-spectrum neutralization of avian and human influenza a viruses. Nat Struct Mol Biol. 2009;16:265-73.

27. Wyrzucki A, Dreyfus C, Kohler I, Steck M, Wilson IA, Hangartner L. Alternative recognition of the conserved stem epitope in influenza a virus hemagglutinin by a $\mathrm{V}_{\mathrm{H}} 3-30$-encoded Heterosubtypic antibody. J Virol. 2014;88:7083-92.

28. Corti D, Suguitan AL Jr, Pinna D, Silacci C, Fernandez-Rodriguez BM, Vanzetta F, Santos C, Luke CJ, Torres-Velez FJ, Temperton NJ, et al. Heterosubtypic neutralizing antibodies are produced by individuals immunized with a seasonal influenza vaccine. J Clin Invest. 2010;120:1663-73.

29. Kashyap AK, Steel J, Rubrum A, Estelles A, Briante R, llyushina NA, Xu L, Swale RE, Faynboym AM, Foreman PK, et al. Protection from the 2009 H1N1 pandemic influenza by an antibody from combinatorial survivorbased libraries. Plos Pathog. 2010;6:e1000990.

30. De Marco D, Clementi N, Mancini N, Solforosi L, Moreno GJ, Sun X Tumpey TM, Gubareva LV, Mishin V, Clementi M, Burioni R. A non-VH1-69 heterosubtypic neutralizing human monoclonal antibody protects mice against $\mathrm{H} 1 \mathrm{~N} 1$ and $\mathrm{H} 5 \mathrm{~N} 1$ viruses. Plos One. 2012;7:e34415.

31. Friesen RH, Lee PS, Stoop EJ, Hoffman RM, Ekiert DC, Bhabha G, Yu W, Juraszek J, Koudstaal W, Jongeneelen M, et al. A common solution to group 2 influenza virus neutralization. Proc Natl Acad Sci U S A. 2014:111:445-50.

32. Tan GS, Lee PS, Hoffman RM, Mazel-Sanchez B, Krammer F, Leon PE, Ward AB, Wilson IA, Palese P. Characterization of a broadly neutralizing monoclonal antibody that targets the fusion domain of group 2 influenza a virus hemagglutinin. J Virol. 2014:88:13580-92.

33. Henry Dunand CJ, Leon PE, Kaur K, Tan GS, Zheng NY, Andrews S, Huang M, Qu X, Huang Y, Salgado-Ferrer M, et al. Preexisting human antibodies neutralize recently emerged H7N9 influenza strains. J Clin Invest. 2015;125:1255-68.

34. Laursen NS, Friesen RHE, Zhu X, Jongeneelen M, Blokland S, Vermond J, van Eijgen A, Tang C, van Diepen H, Obmolova G, et al. Universal protection against influenza infection by a multidomain antibody to influenza hemagglutinin. Science. 2018;362:598-602.

35. Dreyfus C, Laursen NS, Kwaks T, Zuijdgeest D, Khayat R, Ekiert DC, Lee JH, Metlagel Z, Bujny MV, Jongeneelen M, et al. Highly conserved protective epitopes on influenza B viruses. Science. 2012;337:1343-8.

36. Corti D, Voss J, Gamblin SJ, Codoni G, Macagno A, Jarrossay D, Vachieri SG, Pinna D, Minola A, Vanzetta F, et al. A neutralizing antibody selected from plasma cells that binds to group 1 and group 2 influenza a hemagglutinins. Science. 2011;333:850-6.

37. Wu Y, Cho M, Shore D, Song M, Choi J, Jiang T, Deng YQ, Bourgeois M, Almli $\mathrm{L}$, Yang $\mathrm{H}$, et al. A potent broad-spectrum protective human monoclonal antibody crosslinking two haemagglutinin monomers of influenza a virus. Nat Commun. 2015;6:7708.

38. Clementi N, De Marco D, Mancini N, Solforosi L, Moreno GJ, Gubareva LV, Mishin V, Di Pietro A, Vicenzi E, Siccardi AG, et al. A human monoclonal antibody with neutralizing activity against highly divergent influenza subtypes. Plos One. 2011;6:e28001.

39. Tharakaraman K, Subramanian V, Viswanathan K, Sloan S, Yen H-L, Barnard DL, Leung YHC, Szretter KJ, Koch TJ, Delaney JC, et al. A broadly neutralizing human monoclonal antibody is effective against H7N9. Proc Natl Acad Sci. 2015;112:10890-5.

40. Kallewaard NL, Corti D, Collins PJ, Neu U, MCAuliffe JM, Benjamin E, Wachter-Rosati L, Palmer-Hill FJ, Yuan AQ, Walker PA, et al. Structure and function analysis of an antibody recognizing all influenza a subtypes. Cell. 2016;166:596-608.

41. Jacobsen H, Rajendran M, Choi A, Sjursen H, Brokstad KA, Cox RJ, Palese P, Krammer F, Nachbagauer R. Influenza virus hemagglutinin stalk-specific antibodies in human serum are a surrogate marker for in vivo protection in a serum transfer mouse challenge model. MBio. 2017;8:e01463-17.

42. Neumann $\mathrm{G}$, Watanabe $T$, Ito $\mathrm{H}$, Watanabe $\mathrm{S}$, Goto H, Gao P, Hughes $\mathrm{M}$, Perez DR, Donis R, Hoffmann E, et al. Generation of influenza a viruses entirely from cloned cDNAs. Proc Natl Acad Sci. 1999;96:9345-50.

43. Xie S, Shi Y, Gong R, Cui W, Jiang Y, Liu M, Wang L, Zhou H, Qiao X, Li $Y$, et al. Identification of antigenic epitopes of monoclonal antibodies against the VP2 protein of the 25 serotype of bluetongue virus. Vet Microbiol. 2018;219:136-43.

44. Chiu C, Ellebedy AH, Wrammert J, Ahmed R. B cell responses to influenza infection and vaccination. Curr Top Microbiol Immunol. 2014;386:381-98.

45. Li C, Yu K, Tian G, Yu D, Liu L, Jing B, Ping J, Chen H. Evolution of H9N2 influenza viruses from domestic poultry in mainland China. Virology. 2005;340:70-83.

46. Li X, Shi J, Guo J, Deng G, Zhang Q, Wang J, He X, Wang K, Chen J, Li Y, et al. Genetics, receptor binding property, and transmissibility in mammals of naturally isolated H9N2 avian influenza viruses. PLoS Pathog. 2014;10:e1004508.

47. Sano K, Ainai A, Suzuki T, Hasegawa H. The road to a more effective influenza vaccine: up to date studies and future prospects. Vaccine. 2017;35:5388-95.

48. Osterholm MT, Kelley NS, Sommer A, Belongia EA. Efficacy and effectiveness of influenza vaccines: a systematic review and meta-analysis. Lancet Infect Dis. 2012;12:36-44.

49. Okuno Y, Isegawa Y, Sasao F, Ueda S. A common neutralizing epitope conserved between the hemagglutinins of influenza a virus $\mathrm{H} 1$ and $\mathrm{H} 2$ strains. J Virol. 1993;67:2552-8.

50. Corti D, Cameroni E, Guarino B, Kallewaard NL, Zhu Q, Lanzavecchia A. Tackling influenza with broadly neutralizing antibodies. Curr Opin Virol. 2017:24:60-9

51. Wu NC, Wilson IA. Structural insights into the design of novel anti-influenza therapies. Nat Struct Mol Biol. 2018:25:115-21.

52. Bangaru S, Lang S, Schotsaert M, Vanderven HA, Zhu X, Kose N, Bombardi R, Finn JA, Kent SJ, Gilchuk P, et al. A Site of Vulnerability on the Influenza Virus Hemagglutinin Head Domain Trimer Interface. Cell. 2019;177:11361152.e1118.

53. Lee J, Boutz DR, Chromikova V, Joyce MG, Vollmers C, Leung K, Horton AP, DeKosky BJ, Lee CH, Lavinder JJ, et al. Molecular-level analysis of the serum antibody repertoire in young adults before and after seasonal influenza vaccination. Nat Med. 2016;22:1456-64.

\section{Publisher's Note}

Springer Nature remains neutral with regard to jurisdictional claims in published maps and institutional affiliations.

Ready to submit your research? Choose BMC and benefit from:

- fast, convenient online submission

- thorough peer review by experienced researchers in your field

- rapid publication on acceptance

- support for research data, including large and complex data types

- gold Open Access which fosters wider collaboration and increased citations

- maximum visibility for your research: over 100M website views per year

At BMC, research is always in progress.

Learn more biomedcentral.com/submissions 